\title{
Role of Insurance Ombudsman and Grievance Management in Life Insurance Services in Indian perspective
}

\author{
Rajesh K. Yadav ${ }^{1, *}$, Sarvesh Mohania ${ }^{2, \star *}$ \\ ${ }^{1}$ Maxim Institute of Technology, Bhopal (M.P.) India \\ ${ }^{2}$ CRIM (UTD), Barkatullah University, Bhopal (M.P.), India

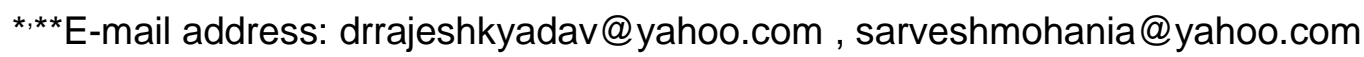

\begin{abstract}
A grievance is defined as a wrong or immoral suffered which creates ground for a complaint. In other words, dissatisfaction of customer on a product or service offered by a manufacturer or a service provider. The study focuses on the grievance management in life insurance services by the insurance ombudsman in India. In today's scenario of insurance market, with the large volume of insurance transactions and huge customer size, it is an accepted fact that there will be growing number of policyholder grievances for every insurance providing company. The study is based on the secondary data collected from IRDA and research papers from various journals. The study concluded that in grievance management role of insurance ombudsman is very important and constant increase in number of complaints received by various Ombudsman all across the India shows that the policyholders are gaining their confidence and trust in the institution of Insurance Ombudsman.
\end{abstract}

Keywords: Grievance; Life Insurance; Insurance Ombudsman

\section{INTRODUCTION}

Historically insurance industry has been necessarily dealing with vast numbers. In fact last decade has seen a remarkable growth - both in the number of policies as well as the premium incomes of life insurance in the India. The dark side of this growth has brought large numbers of consumer complaints and grievances. However, if one were to conduct a study of a proportionate relationship between life insurance business growth and its grievances, it is very possible that the number of customer related grievances has not increased by the same proportion that life insurance business has. With the development and increased usages of information technology and its allied services, there should have been a better improvement in the field of dealing with customer related issues. More recently apart from the support of technology, the general awareness of the customers related to their rights and responsibilities 
and the campaigns of consumer bodies that have taken an important jump, should have ensured lesser number of grievances.

Across all corporate entities while there is a vast improvement in the customer service culture, there is still a lot to be desired in achieving appraise worthy status in this matter. One noticeable development in the industry during the last one decade is the emergence of the institution of the Ombudsman. Even though the Ombudsman's office can operate within certain pre-defined set boundaries and limitations, one should see that the institution has contributed a lot in the field of controlling the trend of growing customer dissatisfaction in insurance sector [1-10].

\section{LIFE INSURANCE IN INDIA}

In the year 1818 business of life insurance in India in its existing form started with the establishment of the Oriental Life Insurance Company in Kolkata. It was started by Mr Bipin Behari Dasgupta and Europeans living in India were their primary customers. The first native insurance provider in India was formed in 1870 with the name Bombay Mutual Life Assurance Society. As on till date there are total 24 Life Insurance Companies in India. Life Insurance Corporation of India, ICICI Prudential Life Insurance Company, Bajaj Allianz Life Insurance Company, and HDFC Standard Life Insurance Company Etc., are the few names of Public sector and Private sector companies.

In life insurance there are two important parties to the contract, the policy holder and the insurer. Basically life insurance policies are legal contract between the policy holder and the insurer, terms and conditions are to be describing on it. It is a contract between the policy holder and the insurer to pay nominee a sum of money on the occurrence of the insured person's death or in the case of maturity of the policy, policy holder will receives whatever amount he has deposited as premium plus bonus on it. In return policy holder agrees to pay fix amount of premium on regular basis or in lump sum (one time premium payment) to the insurer.

Life insurance is mainly taken for two objectives, first is for risk coverage and second is for the investment objective.

i) Risk coverage: Lump sum payment is provided if specific event occurred.

ii) Investment: Money is invested with a motive of getting greater return.

Primary purpose of any insurance service is to provide risk against uncertainty. For this risk management, policy holder regularly pays insurance premium to the insurance providing company. However, the risk is intangible and seldom is the need for a risk coverage felt by an individual customer, therefore an extra effort needed to make the customer understand the need for insurance [10].

\section{GREVIANCE MANAGEMENT}

Previously grievances filed by the customers were treated as single cases and single remedies are suggested but with the changing environment, increasing competition and customers' awareness in insurance sector, now grievances are not treated as singular events. In order to gain good competitive edge in the market, cause and effect analysis of the grievances is undertaken, not only as corrective step but as preventive step. By the time, the 
term, 'Grievance Management' has attained a more sensible meaning, usage and importance in insurance industry.

Today grievance management has emerged out to be part of management science subject, which provide clear cut definitions for various behavioral scenarios, trends analysis of grievance, and their classification and quantification of impacts on the insurance services, etc. To be successful, the grievance management system must begin right from the first through the last minute of policyholders contact. In addition to everything else, it includes distinguishing the requirement for grievance redressal and client satisfaction; making the entire association recognize itself with the saying of client pleasure; securing viable system for grievance reporting and redressal. Critically, grievance administration is not a one-time assignment. It is a completely dynamic assignment as in it needs steady observing adjust theclock, $24 \times 7$ and is never said to be finished as long as the business is in presence [5].

\section{1. Insurance Ombudsman}

The foundation of Insurance Ombudsman was made by a Government of India Notification dated eleventh November, 1998 with the motivation behind speedy transfer of the grievances of the safeguarded clients and to alleviate their issues included in redressal of those grievances. This foundation is of incredible significance and importance for the assurance of investment of arrangement holders and likewise in building their certainty in the framework. The foundation has served to produce and support the confidence and certainty amongst the policy holders and insurers.

Insurance Ombudsman has two sorts of function to perform

(1) Appeasement,

(2) Award making.

The Insurance Ombudsman is engaged to get and consider complains from any individual who has any grievance against an insurance providing company. Grievance may be file against the insurance providing company in case of following:

(a) Any partial or total repudiation of claims by the insurance providing company,

(b) Any disagreement concerning premium paid or payable in the insurance policy

(c) Any dispute on the legitimate construct of the wordings in the event of dispute related to claims

(d) Delayed claim settlement and

(e) Even after the receipt of premium, non-issuance of any insurance document i.e. insurance policy.

Insurance ombudsman's powers are confined to insurance policy contracts of worth not exceeding Rs. 20 lakhs. The insurance providing companies are obliged to respect the recompenses passed by an Insurance Ombudsman inside three months [9].

\section{2. Territorial Jurisdiction (Power) of Ombudsman}

The administering body has appointed twelve Ombudsman all over the nation distributing them different part of nation as their power of jurisdiction (Power). The Ombudsman may hold sitting at different places inside their range of ward keeping in mind the end goal to speed up disposal of grievances.

The twelve Insurance Ombudsman offices are found across all over the India at:

(1) Bhopal, 

(2) Bhubaneswar,
(3) Cochin,
(4) Guwahati,
(5) Chandigarh,
(6) New Delhi,
(7) Chennai,
(8) Kolkata,
(9) Ahmedabad,
(10) Lucknow,
(11) Mumbai,
(12) Hyderabad.

\section{3. Mode of Lodging Complaint}

The grievance by an aggrieved person has to be in writing, and addressed to the insurance Ombudsman of the jurisdiction under which the office of the insurance providing company falls. Aggrieved person can also filed grievance through the legal heirs.

\section{4. Before Lodging a grievance}

i) The complainant/Aggrieved person should have filed complain to the insurance providing company and the insurance providing company either should have rejected the complain or the complainant/Aggrieved person have not received any reply within a period of one month after the concerned insurance providing company has received his complaint or he is not satisfied with the reply of the insurance providing company.

ii) The complain must have filed within one year from the date of reply from the insurance providing company.

iii) The same complain on the same subject ought not to be pending with before any court, consumer forum or arbitrator.

\section{5. Ombudsman's recommendations}

When a grievance is settled through the arbitration of the Ombudsman, he/she shall make the recommendations which he thinks fair in the circumstances of the case. Such a recommendation shall be made not later than one month and copies of the same sent to complainant/Aggrieved person and the insurance company/Insurer concerned. If the complainant accepts recommendations, he/she will send a communication in writing within 15 days of the date of receipt accepting the settlement.

\section{6. Award by Ombudsman}

Within a period of three months from the receipt of complain, the ombudsman shall pass an award. For the Insurance companies awards are the judgment which binds them. If the policy holder/aggrieved person is not satisfied with the award of the Ombudsman he/she can file complain in other places like Consumer Forums and Courts for redressal of his/her grievances.

As per the policy-holder's protection regulations, every insurance providing company/insurer shall update the policy holder along with the required policy documents in respect of the insurance Ombudsman in whose jurisdiction his/her office falls for the purpose of grievances redressal arising if any afterward [1]. 


\section{CONCLUSION}

With the increasing number of customer base and number of insurance policies, number of grievances related to life insurance services is also increasing. Therefore, today it is very much essential to have clear cut grievances management system, Insurance ombudsman ensures that every complainant/aggrieved person should be provided good opportunity to raise his/her grievances. Constant increase in number of complaints received by various ombudsman office all across the India shows that the policy-holders are gaining their confidence and trust in the institution of Insurance Ombudsman.

\section{References}

[1] Available from:

http://www.irda.gov.in/ADMINCMS/cms/LayoutPages_Print.aspx?page=PageNo233

[2] Baradhwaj C. L., IRDA Journal 9(11) (2011) 14-19.

[3] Behera N. M., IRDA Journal 9(11) (2011) 30-32.

[4] Desikan R., IRDA Journal 9(11) (2011) 26-29.

[5] Gunturi S. S., Kulkarni R., IRDA Journal 9(11) (2011) 20-25.

[6] Jawaharlal U., IRDA Journal 11(6) (2013) 3.

[7] Kutty Shashidharan, The Journal of Insurance Institute of India XXXVI (2010) 15-45.

[8] Patel Alpesh, IRDA Journal 8(6) (2010) 15-18.

[9] Roy Joydeep, IRDA Journal 9(11) (2011) 11-13.

[10] Yadav Rajesh K., Mohania Sarvesh, Indian Journal of Economics and Development 1(1) (2013) 29-37. 